\title{
TEACHERS PROFESSIONAL MANAGEMENT THROUGH TEACHERS WORKING GROUP (KKG) IN ACEH PROVINCE
}

\author{
Murniati AR 1, Nasir Usman ${ }^{1}$ *, M. Husen 1, Ulfah Irani ${ }^{1}$ \\ 1Universitas Syiah Kuala \\ 1Jl.Hasan Krueng Kalee Darussalam-Banda Aceh, Indonesia \\ * Corresponding Author. Email: nasir@unsyiah.ac.id
}

\begin{abstract}
This study aims to describe the implementation of teachers management professional development through the teachers working group. This study is a mixed research conducted in ten districts / cities spread in Aceh Province, involving 37 Elementary Schools. The subject in this study include core teacher, teachers, chairman of the KKKS (Principal Working Group), as well as education offices chosen by purposive sampling. Data were collected through interviews, observation and documentation. Qualitative data analysis carried out by the procedure or steps such as data reduction, data display, and verification. The results showed that: (1) Profile of KKG in general consists of the components: (a) the legal basis, the name, position, and the nature of the organization, (b) the vision, mission, and futuristic goals, (c) membership, management and organizational structure, (d) basic budget, and (e) the facilities and infrastructure for KKG; (2) The implementation of KKG is done through the regular and development activities; (3) The obstacles encountered in the implementation of KKG include: (a) inadequate facilities and infrastructure, (b) financing needs to be improved, (c) the motivation of teachers is still low, (d) the principal supports to include teachers in routine activities are lacking due priority school activities, and (e) the support of local government and education authorities on the development of KKG is still lack; while (4) KKG development management evaluation done with the steps: (a) the supervision and monitoring, (b) evaluation, (c) reporting, and (d) feedback.

Keywords: management development, professional teachers, teacher working group (KKG)
\end{abstract}

Permalink/DOI: $h$ ttp://dx.doi.org/10.21831/amp.v7i1.24054 


\section{Introduction}

The quality of the educational process is closely related to the success of the professionalism of teachers in teaching and learning activities in the classroom (DarlingHammond, Hyler, \& Gardner, 2017; Petrie $\&$ McGee, 2012). The learning process is not only the interaction between educators, students, media, and learning infrastructure in the setting of educational environment, but also a systematic process through the stages of planning, implementation and evaluation. Teachers as educators exercising their functions in totality education must mobilize all its potential and competence in providing education services for the sake of educating the nation's children (Loewenberg Ball \& Forzani, 2009).

Reffering to Article 1 the Indonesian Law Number 14 the year of 2005 regarding Teachers and Lecturers, it states that teachers are defined as educators who transfer knowledge and teach the norms and values to learners. Teachers as a central point which are directly involved in a process of teaching and learning activities are expected to create an effective and efficient learning that his presence contributed positively to the development of learners. It is also stated by Tanang \& Abu (2014, p. 25) follows.

The students learning achievement depends on the readiness of teachers to do learning activities which are supported by teacher's knowledge and skills, attitude and practice. That is why most of the literatures require a teacher to possess good competences and performance, involve in professional development actively, engage knowledge with the current issues, conduct the tasks ethically, and show commitment or responsibility in teaching practice at school.

Student achievement depends on the readiness of teachers in presenting the learning process supported by the mastery of competence, engaging actively in professional development, integrity, responsibility, and a commitment to the institution of education and learning. Teachers as professional must meet competency standards to be able to perform the duties and obli- gations as a good and competent educators. Because learning quality is closely related to the quality of educators. Teachers play a central as knowledge experts and the deliverers of knowledge, ensure calm and concentration in the classroom and do not attend to the needs of the individual students but instead treat the whole class as a kind of collective students (de Vries, van de Grift, \& Jansen, 2013).

The professional competence of teacher, related about the ability of educators in carrying out the primary task to manage the class. Professional competence is also the ability of teachers to master, develop learning materials, as well as utilize technology effectively in order to improve the quality of teaching and learning. A teacher must continue to increase their knowledge in improving achievement and good performance through training, coaching and so on. To develop the competence of teachers required seriousness and awareness of the importance of teacher professional development policies in the face of developments in science and technology is so rapid and unstoppable. Coaching and professional development programs for educators would be a wise step that can be done by analyzing the needs of institutions, groups and individuals, educators themselves with reference to the development of national standards that have been set. From the institutional perspective, the development educators are expected to stimulate, maintain, and improve the quality of teachers in the learning process in accordance with the development of science and technology. Because the substance of the study and learning contexts are always evolving and changing to adjust the dimensions of space and time, so it is not surprising that teachers are required to always improve their competence.

One of the efforts of educators professional development can be done through strengthening the performance of Teachers Working Group (KKG). KKG can be a forum for development and training of educators in order to repair and improve the competence of educators related about the development of teaching materials, models, 
learning techniques, research methods class action as well as solving the problem of teachers through dialogue, sharing experiences with peers, as well as collocuium and lesson study (Alwi, 2009; Husna, 2016; Juwairiyah, 2014; Purnanda, 2013).

This study aims at describe the profile, implementation, obstacles, and evaluation of teachers management professional development through the teachers working group (KKG). The reserach questions of the study are: (1) How is the profile of teachers' working group (KKG) in Aceh?; (2) How is the implementation of teachers' working group in Aceh?; (3) What are obstacles in implementing teachers' working group in Aceh?; How is the evaluation of teachers' working group in Aceh?

\section{Research Method}

This study is a mixed research. The purpose of this study is to describe systematically, both through word and figures about the facts and the information found during the course of the study. By combining qualitative and quantitative research is expected to bring an accurate picture of the phenomenon and research findings. This study conducted at 37 Public Schools in Aceh province, respectively in (1) Banda Aceh, (2) Great Aceh, (3) Lhokseumawe, (4)
Pidie Jaya, (5) Bireuen, (6) Sigli, (7) the municipality of Sabang, (8) West Aceh, (9) Central Aceh and (10) Southwest Aceh.

The unit of analysis in this research is a core teacher, member of KKG, the chairman of the Principals Working Group, and the ministry of education officer on the implementation of basic education in the Province. The sampling technique used was purposive sampling.

Data collected through observation, interviews and documentation study. To obtain valid and reliable analysis that used triangulation analysis techniques. While data analysis is done in three steps, namely (1) the reduction of the data; (2) display; and (3) the conclusion and verification.

\section{Results and Discussion}

The Profile of Primary Teachers Working Group (KKG) in Aceh Province

Teachers Working Group (KKG) is an organization established to assist teachers in improving the professionalism of teachers. KKG consists of several elementary schools that are members of certain groups, where there are schools and school-induced core. The KKG profile, based on the study by the author documentation consists of the following components.

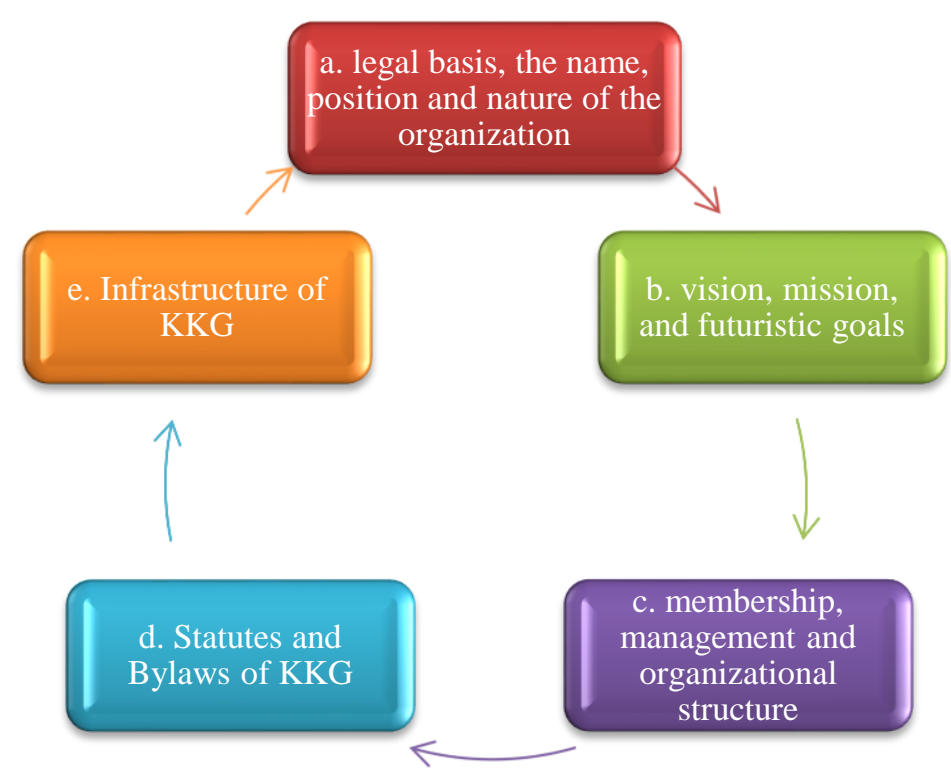

Figure 1. Main Components of Teachers Working Group (KKG) Profile 
The Basic Law, Name, Position and The Nature of Organization

Teachers Working Group (KKG) is an organization/association of classroom teachers and subjects are domiciled in certain sub-districts joined in a cluster, such as cluster I, Cluster II, Cluster XX and so on. KKG organizations sufficiency based on kinship, deliberation, and consensus, are independent based on the principle of independence that promotes the alignment of partners with various parties, and is not a new bureaucracy.

\section{Vision, Mission and Futuristic Objectives}

KKG's vision and mission in general focuses on improving teacher competence and learning process. The following is excerpt KKG vision and mission based on fragmentary interview with the chairman of the group 1 Sukakarya District of Sabang: "The vision is to create competence KKG qualified teachers, have the ability to develop the education of students and has a personality that is responsible, while the mission of KKG, among others: (1) improving the competence of teachers in quality learning; (2) increase the ability of teachers in the development of an optimal education of students; (3) improve the competence of teachers who have a strong personal, responsible and a role model for students".

In addition, based on the study of documentation and interviews with the entire subject of research obtained information that KKG aims to: (1) improve and equalizes the competence of teachers in implementing the learning activities in the efforts to improve the quality of education equalization; (2) develop the competence of teachers in the preparation of learning devices either individually or in groups, such as: (a) the preparation of syllabus; (b) book reviews; (c) the preparation of teaching materials; (d) assessment refers to the competence standard, basic competence and indicator, (3) prepare and help teachers solve/discuss the problems faced by teachers in carrying out their professional duties, (4) instill a sense of responsibility of the teachers to carry out their main tasks both in the classroom and outside the classroom; (5) preparing teachers who are creative, innovative, competitive, and professional through referrals, guidance from relevant parties such as the Education Office, supervisors, and the chairman of the group, (6) motivate teachers to improve the abilities and skills in plan, implement, and evaluate programs of learning activities, lays out/formulate the reform agenda of the school (school reform) in order to improve self-confidence as a professional teacher, and processed reoreintated effective and efficient learning, (7) Assisting teachers in obtaining information from various sources (results of workshops, seminars, workshops, curriculum activities, and others., (8) develop a culture of conducive classroom as a fun learning process and educating students, (9) establish partnership with fellow teachers and community partners in the success of the learning process, (10) improving the quality of education which is reflected through improved student learning outcomes.

The Membership, Management and Organizational Structure of KKG

As for the procedure for membership of the KKG was involving all the teachers who are in a particular cluster that consists of goverment teachers and non government teachers who teach classes and certain subjects in a specific sub-district under the auspices of the Ministry of Education and Culture. Generally, the number of teachers involved in any KKG reach \pm 100 people. Chairman of Cluster II that "membership in the cluster II attendees registered online to become teachers in KKG community".

In addition, the chairman of the KKG Cluster 1 Kebayakan, Central Aceh district suggests that, "the establishment of the caretaker of the KKG done by their respective schools in sending representatives to be selected into a KKG sysop". Further, the Chairman of the KKG Core Cluster IV Kuta Batee, Pidie Jaya adds that:

the mechanism of the formation of KKG's caretaker done joint deliberation with teachers and principals, all representatives of 
each school that has been chosen as the core, which is further designated some teachers to fill the position as Coordinator Teacher (teacher guides or class guide subjects).

Linked to the establishment of KKG organizational structure set out in statutes and bylaws of KKG. The field of development set out in the organizational structure of KKG is determined based on their individual needs based on the results of consultation with KKG. Here's one of the models of organizational structure KKG.

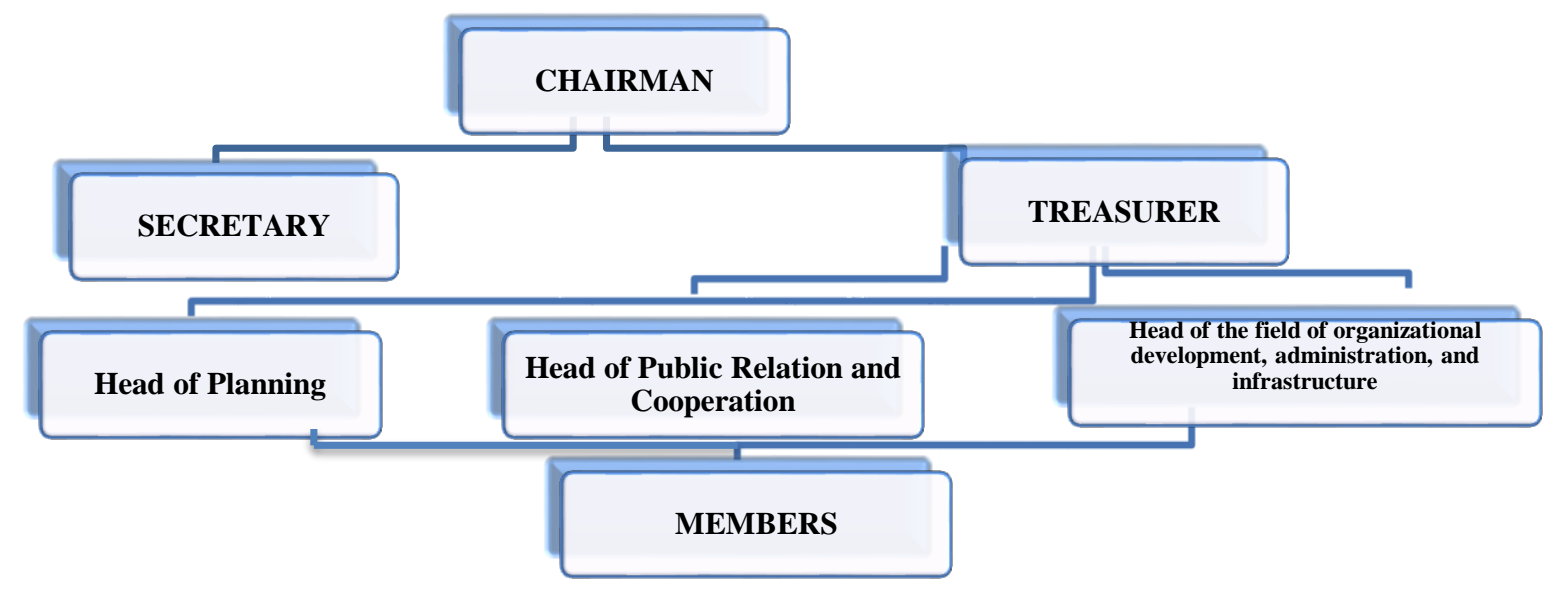

Figure 2. Structure Model of KKG

Statutes and Bylaws of KKG

Statutes and bylaws drawn up by the board of KKG. KKG administrators and principals forum (KKKS) formulate the KKG budget for the period of one year of activity. The statutes can only be changed by a meeting of KKG deliberately held for that purpose. The amendment conference shall be attended at least two-thirds of the total membership of KKG. Meeting Decisions amendment is considered valid if approved by two thirds of the members present.

Fasilities and Infrastructure of KKG

Based on interviews with the subjects of the study obtained information on the availability of facilities and infrastructure supporting the organization of KKG obtained as follows.

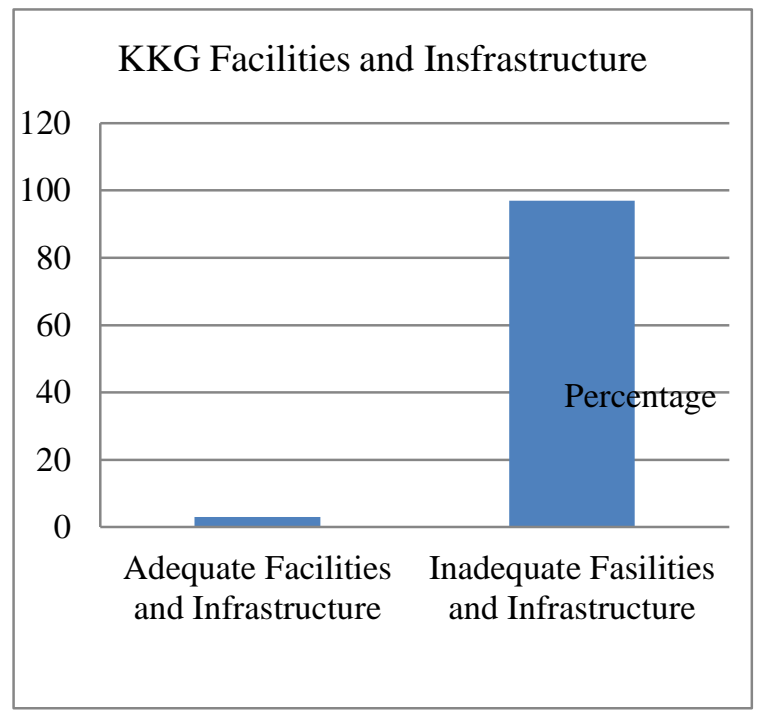

Figure 3. Percentage of KKG

Availability Infrastructure in Aceh Province

Diagram above shows that $97 \%$ of respondents argued that the availability of infrastructure remains inadequate so that the implementation is not well organized. Some KKG also does not have a separate room used for the activities of KKG. 
Implementation of Teachers Professional Development Management through Teachers Working Group (KKG) In Aceh

In implementing the programs and activities, primary teachers working group in Aceh conducted some activities and programs as below.

\section{Routine Activities}

Routine activities are organized every week and scheduled well. However, in practice, most members stated that the KKG often does not conduct routine $\mathrm{KKG}$, only sometimes there was a meeting at the end of the semester, include: (a) discussion of learning problems, (b) the preparation of the syllabus, lesson plans and semester programs, (c) analysis of the curriculum, (d) the preparation of the learning evaluation instruments; (e) discussion on materials and strengthening of national exams.

\section{Development Activities}

The development activities are organized to support the routine programs and to increase the teachers' knowledge and competences, such as: (a) research, (b) writing scientific papers, (c) seminars, workshops, kolosium, and panel discussions, (d) education and workshop, (e) issuance of KKG's journal, (f) preparation of KKG website, (g) implement the KKG forum, $(\mathrm{h})$ peer coaching (training fellow teachers using ICT media).

The percentage contribution of the implementation of KKG realization presented in the following diagram (Figure 4).

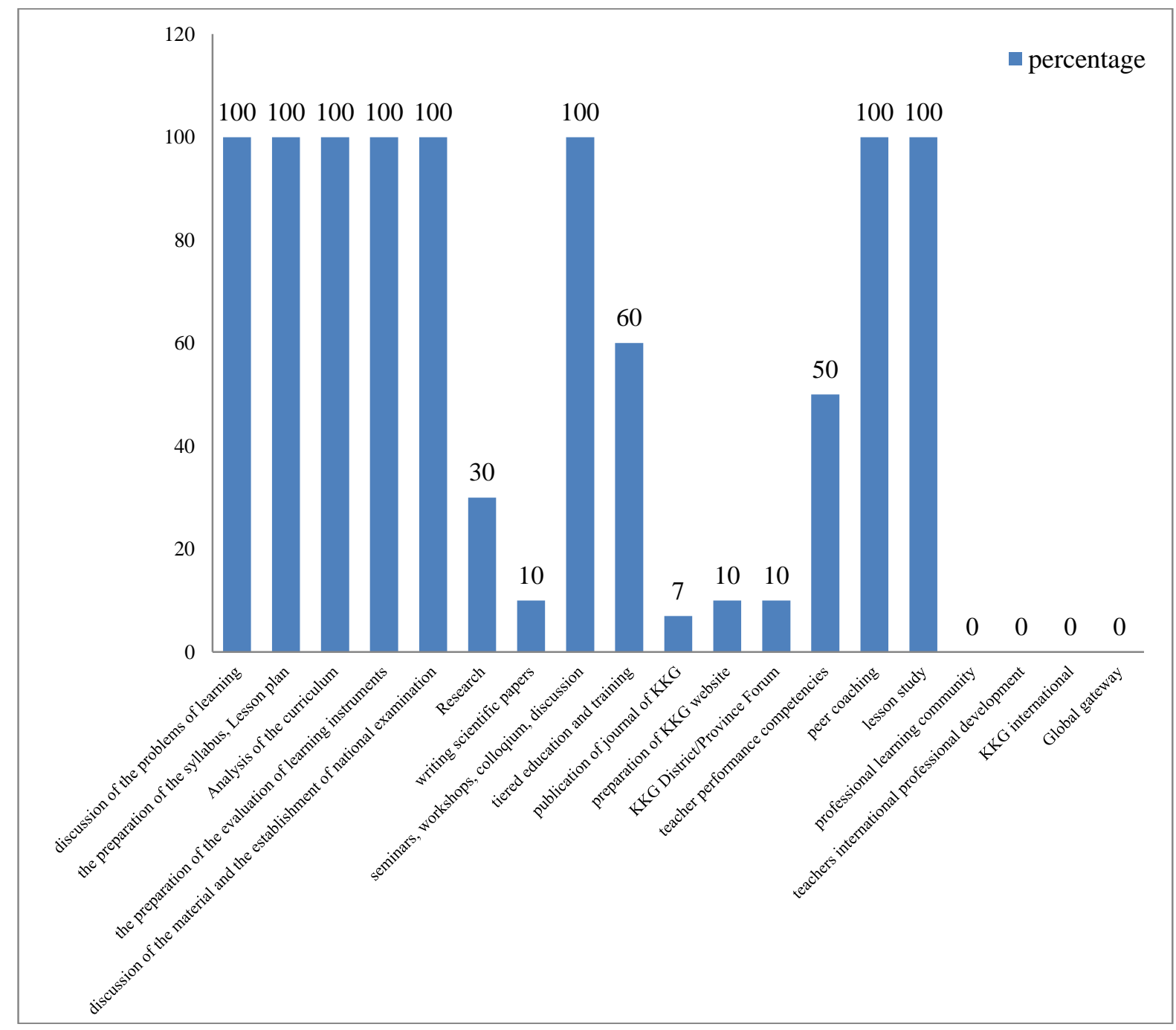

Figure 4. The Realization of KKG's Activities in Aceh 
Based on the diagram above is known that all research subjects $(100 \%)$ of KKG or 37 KKG in Aceh province has held: (1) discussion of the problems of learning, (2) the preparation of the syllabus and lesson plan (3) analysis of the curriculum, (4) preparation instruments and evaluation of learning, and strengthening of the material dealing with the national examination, (5) seminars, workshops, colloqium, and discussions, (6) peer coaching, and (7) lesson study. While $29.72 \%$ or $11 \mathrm{KKG}$ has done research, $10.81 \%$ or $4 \mathrm{KKG}$ has done writing scientific papers, $59.46 \%$ or $22 \mathrm{KKG}$ has organized education and training phases, $8.10 \%$ or $3 \mathrm{KKG}$ has organized publishing KKG's journal, 10.81\% or 4 KKG has mainstreamed website, $10.81 \%$ or $4 \mathrm{KKG}$ has followed Forum districts / provinces, and $51.35 \%$ or 17 KKG has organized the efforts of increasing the competence of teacher performance.

In this case, the teachers' forum as KKG may be one way to develop the competence of teachers in which also involves the sharing of opinions with senior teachers and the speaker on his field, of course.
The Obstacles in Implementing Teachers' Working Group (KKG) in Aceh

Based on the results of interviews with members of KKG which became the subject of the information obtained in this study that the obstacles encountered in implementing KKG include: (a) infrastructure and facilities that are inadequate, (b) financing needs to be improved, (c) teacher motivation still low, (d) principal support in including his teachers in regular activity is still less because of the priority activities of the school, (e) support of local government and education authorities on the development of KKG is still lack

Evaluation of Professional Development of Teachers Through the Teachers Working Group (KKG) In Aceh

The KKG development management evaluation carried out with the following steps:

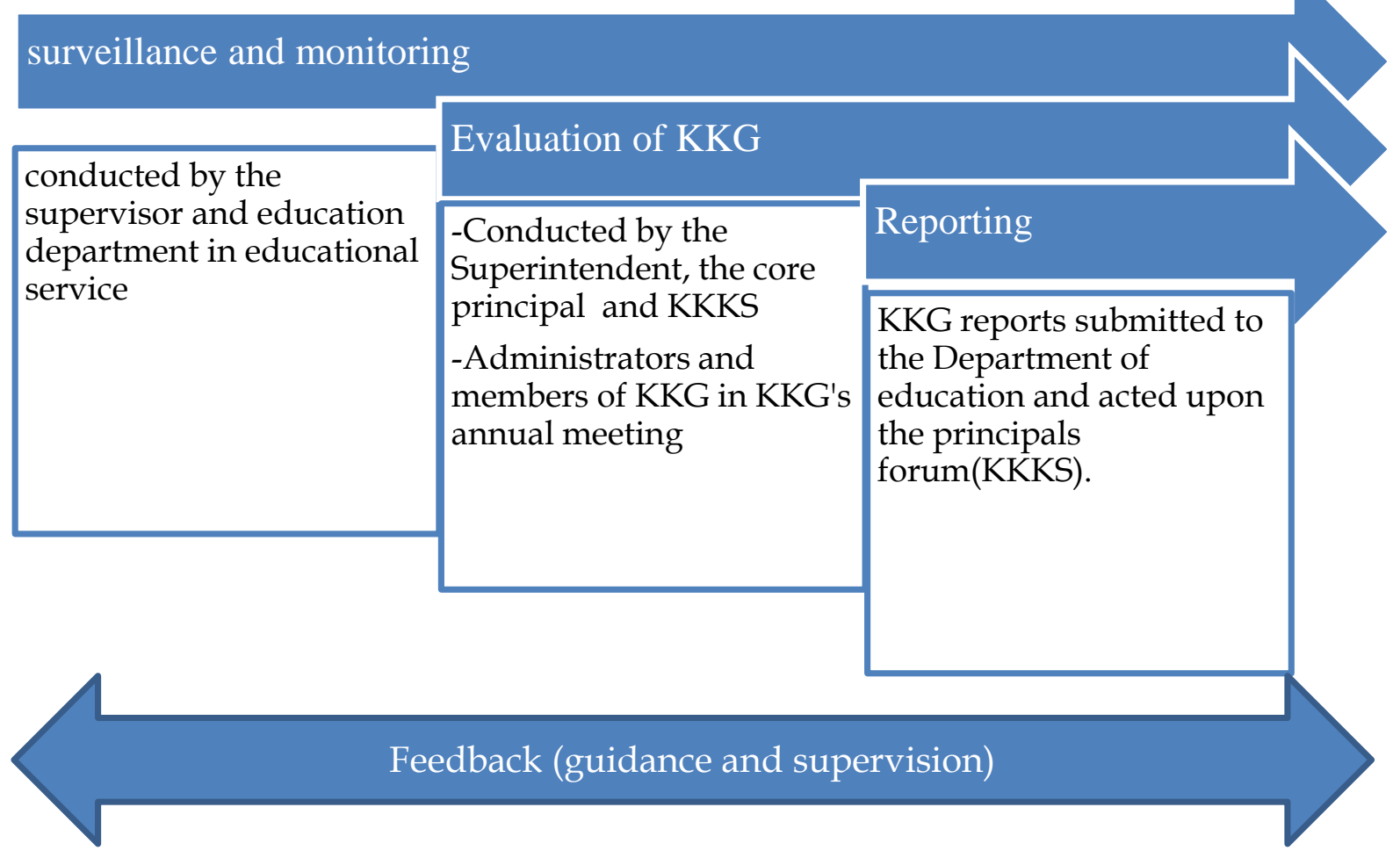

Figure 5. The Stages of Evaluation Management of KKG in Aceh Province 
There are a series of activities evaluation of KKG which is done based on the picture above. First, on the stage of surveillance and monitoring, supervisor and educational department office survey and monitor the activities and programs conducted by KKG in every meeting.

Second, after a series of surveillance and monitoring activities are carried out, at the end of the semester was held KKG's annual meeting involving the superintendent, the core principals and administrators, KKKS and members of KKG which discusses the achievement of the target and the failure of the program that have been held. Further evaluation is carried out taking into account the various feedback and criticism given by all participants of the meeting to be followed up. So that, there will be the presence of improvement against the activity and program activity KKG in the future. After the evaluation was done, then the sysop of KKG will generate a report against the results of the KKG's annual meeting.

Third is reporting. At this stage, the caretaker of the KKG report accountability Executive Board submitted to the Department of education and acted upon the principals (KKKS) for follow up. But based on the interview with the chairman of some KKG in Aceh obtained information that the monitoring and evaluation of KKG is not done routinely performed each year by district and province educational office. At lat, feedback is given to correct and increase KKG's activities.

\section{Discussion}

The professionalism of educators is a key condition to improve the quality of learning. Professionalism is an effort to augment its competence by way of self-motivating to increase capabilities and expertise that has been held at this time in order to grow and support the professional career. Professional development of educators is an extrinsic efforts undertaken in support of improving the performance of teachers. A professional development for teachers is recognized as a key vehicle through which to improve teaching, and in turn, to improve student achievement (Petrie \& McGee, 2012). Many efforts should be made to develop teachers' professional self-development such as: (1)study the teaching material / subject matter main task of learning; (2) develop insight and knowledge from various sources in order to support the enrichment of source/learning materials, through reading relevant literature, active participation of teacher working groups, consultation with school principals, supervisors and speakers, and others, (3) study and master competencies subjects to be taught to students, (4) studied and controlled forms of classroom management, (5) study and master forms of learning technology and its use, (6) to learn and master the media forms of learning and use, (7) studied and mastered the learning and use of evaluation forms (Agung \& Yufridawati, 2013). The above statement mentioned that KKG can be one of the solutions of increased competence of teachers. It shows that KKG is an alternative effective teacher professional development.

In preparing professional teachers required sustained efforts through the preparations. Loewenberg Ball \& Forzani (2009), mentioned that making practice is the core of teachers' professional preparation while teaching practice against the contemporary backdrop of a teacher education curriculum that is often centered not on the tasks and activities of teaching but on beliefs and knowledge, on orientations and commitments, and a policy environment preoccupied with recruitment and retention. Teachers need to experience 'on-going sessions of learning, collaboration, and application, accompanied by school- and classroom-based support, over an ample time period (Killion, 2005). The statement has been said by Loewenberg Ball \& Forzani (2009) above confirms that the need of practice teaching for teachers so that teachers can prepare in all activities and tasks taught in school. It is in line with routine activity and development activities organized in forums such as KKG expressed in Figure 4 above, it can be said that KKG is a 
line with the continuing professional development (CPD) of teacher.

(Hidayah \& Sugiarto $(2015$, p. 44$)$ also added that the implementation of KKG contribute more positively than training organized by other institutions in developing professional teacher as follows: "teachers' working group is more effective and efficient than training forums held by institutions such as education quality improvement institutions, higher education office, and education office in terms of implementing successful learning, which is appropriate to the characteristics and needs of learners and environmental potential".

Development through groupings like KKG is believed to provide great benefits to the development of teacher competence as proposed by Chantathai, Tesaputa, \& Somprach (2015) that "the program on teamwork development for teacher efeciency in the municipal school would be useful for professional and application. Since its effectiveness for competency development, this is recommended based on five aspects: operational effectiveness, service excellence, self-development, teamwork, and teacher ethics, teamwork is highly emphasized for teacher professional development to achieve the national standard.

The above statement is not much different from the statements expressed by before, where the purpose is achieved through the implementation of KKG, among others: " planning activities for a year guided by a supervisor or trainer; the teacher's accomodating and solving problems in the learning activities through meetings, discussions, learning demonstration, using Demonstration, and develop a workshop of teaching aids" (Hidayah \& Sugiarto, 2015).

In addition, Goodwin \& Kosnik (2013) stated that there are some knowledge domains for teaching are: (1) personal knowledge/autobiography and philosophy of teaching; (2) contextual knowledge/ understanding learners, schools, and society; (3) pedagogical knowledge/content, theories, teaching methods, and curriculum development; (4) sociological knowledge/ diversity, cultural relevance, and social justice, and (5) social knowledge/cooperative, democratic group process, and conflict resolution.

The existence of the KKG was able to improve the performance of teachers in carrying out his professional duties and obligations. Teacher performance is a synergistic elements that must be developed to produce the professional educators who are competent to a process of education relevant to the situation, condition, and needs of the community, as such, the performance of the teacher quality will be capable of producing qualified human resources, so as to improve the quality of school (Purwoko, 2018).

Loewenberg Ball \& Forzani (2009) added that professional teachers can be obtained by focused on developing newpathway to teaching, fundamental renovations to curriculum of profesional education for teachers, whereever and through whatever pathway is occurs. We claim that practice must be at the core of teachers' preparation and that this entails close and detailed attention to work of teaching and development ways to train people to do that work effectively, with direct attention to fostering equitably the educational opportunities for which schools are responsible.

Referring to the routine activities and development carried out by KKG in Aceh Province, further, the step to increase professional development of teachers can also be done through education and training in the form of technological guidance, spiritual quantum learning, further studies, development through working groups of teachers, recitation activities and development (Muniroh \& Muhyadi, 2017). By adding a component of the development of spiritual quantum, further learning, recitation activities and the development is expected to increase teachers who not only have the potential for good professional but also the competence of good spiritual so that the professionals teachers are not only have the capacity of knowledge and skills, but also ethical and behavioral which can be a role model and example for the environment. 
KKG as a part of professional development offers all natural learning experiences and those conscious and planned activities which are intended to be of direct and indirect benefit to individual, group, or school, which contribute to the quality of education in the classroom, it is process by which, alone, or with others, teachers review, renew and extend their commitment as change agents to the moral purpose of teaching; and by which they acquire and develop critically the knowledge, skills, and emotional intelligence essential to good professional thinking, planning, and practice with children, young people, and colleagues throughout each phase of their teaching activities (Day, 1999).

Further, based on the research findings about primary teachers' developmenet management through KKG in Aceh Province, it can be concluded that the implementation of KKG in Aceh province has been referred to the standards development working groups of teachers (KKG) of Educational Ministry of Indonesia include program, organization, management, human resources, and budget standards. But, KKG in Aceh still not fulfilled by the facility and insfrastructure standard, and quality assurance standards (Direktorat Profesi Pendidik Direktorat Jenderal Peningkatan Mutu Pendidik dan Tenaga Kependidikan, 2008). Strengthening in the evaluation of KKG is needed, so that the continuity and effectiveness of KKG in developing teachers' professional can be well controlled and increased. Therefore, the supervision of KKG/MGMPs necessary to know the activities of its goals, the ratio between the activity/real standards are achieved, determine and measure the degree of deviation that can be done through:

Fisrt, Supervision by the school principal: (a) direct observation in KKG like observing planning of KKG, implementation of KKG, where the implementation of spatial management, good professional attitude of officials, participating teachers in $\mathrm{KKG}$, urging and implementation of activities, (b) examination of the attendance list, (c) evaluating of KKG, (d) meeting on a board of teachers

Second, supervision by the supervisor /District Education Office: (a) supervisory/ stakeholders made visits to target schools, (b) supervisory / stakeholders observe learning activities, success and progress achieved and the constraints faced (Idris, 2013).

To increase the participation of teachers in professional development management, it needed to make mature planning and implementation of training programs, development, workshops, seminars and so on and the attractive activities for teachers to be followed. As the revelation expressed by Lessing \& Witt (2007) that in the presentation of workshop for teachers, presenters shoud focus on the principles underlying continuous professional development since teachers are likely to be more willing to attend workshops if they are worth the time spent, and sacrificies made.

\section{Conclusions}

Based on the results of data analysis we can conclude several things, including:

First, profile of KKG consists of components (a) legal basis, the name, position and nature of the organization; (b) the vision, mission, and futuristic goals, (c) membership, management and organizational structure, (d) the constitution and bylaws of KKG, (e) the facilities and infrastructure of KKG.

Second, implementation of KKG implemented based on an analysis of the needs of teachers and have followed KKG activity plan that has been prepared in consultation of KKG. The routine activities and development which include: (1) discussion of the problems of learning, (2) syllabus adn lesson plan, (3) analysis of the curriculum, (4) the preparation of an evaluation instrument of learning, (5) the material and the stabilization of facing the National Examination, (6) research, (7) writing scientific papers, (8) seminars, workshops, colloqium, discussion, (9) the education and training phases, (10) journal publishing of KKG, (11) the preparation of the KKG's website, (12) 
districts/province forum of KKG, (13) the competence of the teacher's performance, (14) peer coaching and (15) lesson study. While KKG in Aceh province have not been incorporated in professional learning community of international teachers professional development.

Third, the KKG development management evaluation conducted by the steps include (1) control and monitoring carried out by the supervisor in the education, (2) evaluation of KKG were committed by supervisors and educational department, school principals, administrators and members of KKG in the annual meeting, (3) reporting; KKG report submitted to the Department of Education and followed up to the school principal.

Fourth, as for the obstacles encountered in the implementation of KKG are motivation and working conditions sometimes hamper the implementation of KKG.

Based on the findings and discussion it is suggested that: (a) educators and principals are expected to continue to improve the competence and capability through education and training and active role in the activities of KKG or K3S forum, (b) the commitment of the KKG's participants which are urgently needed in the success of the KKG so as to provide a positive contribution to the professional development of teachers, (c) the active involvement of the supervisor, governments and other education stakeholders is needed in order to optimize mastery of the material and delivery quality assurance of KKG.

\section{References}

Agung, I., \& Yufridawati. (2013). Pengembangan pola kerja harmonis dan sinergis; antara guru, kepala sekolah, dan pengawas, paduan meningkatkan kompetensi bagi guru, kepala sekolah, dan pengawas. Jakarta: Bestari Buana Murni.

Alwi, M. (2009). Peran kelompok kerja guru (KKG) dalam meningkatkan profesional guru sains sekolah dasar Kecamatan Suralaga. Jurnal EducatiO,
$4(2)$.

Chantathai, P., Tesaputa, K., \& Somprach, K. (2015). Development of effective teacher program: teamwork building program for Thailand municipal schools. International Education Studies, 8(19), 138-147.

Darling-Hammond, L., Hyler, M. E., \& Gardner, M. (2017). Effective teacher profesional development. Toronto: Learning Policy Institute.

Day, C. (1999). Developing teachers: the challenges of lifelong learning. London: Falmer Press.

de Vries, S., van de Grift, W. J. C. M., \& Jansen, E. P. W. A. (2013). Teachers beliefs and continuing professional development. Journal of Educational Administration, 51(2), 213-231. https://doi.org/10.1108/09578231311 304715

Direktorat Profesi Pendidik Direktorat Jenderal Peningkatan Mutu Pendidik dan Tenaga Kependidikan. (2008). Standar pengembangan Kelompok Kerja Guru (KKG), Musyawarah Guru Mata Pelajaran (MGMP). Jakarta: Departemen Pendidikan Nasional.

Goodwin, A. L., \& Kosnik, C. (2013). Quality teacher educators $=$ quality teachers? Conceptualizing essential domains of knowledge for those who teach teachers. Teacher Development, 17(3), 334-346.

https:// doi.org/10.1080/13664530.201 3.813766

Hidayah, I., \& Sugiarto. (2015). Model of independent working group of teacher and its effectiveness towards the elementary school teachers' ability in conducting Mathematics Learning. Procedia-Social and Behavioral Sciences, 214(x), 44-48.

Husna, F. (2016). Peran musyawarah guru mata pelajaran (MGMP) untuk meningkatkan kompetensi profesional guru PAI: studi kasus MGMP PAI 
SMP Negeri Kabupaten Kediri. Didaktika Religia, 4(2), 205-224. https://doi.org/10.30762/didaktika.v 4.i2.p205-224.2016

Idris, A. (2013). Pemberdayaan MGMP menuju profesionalisme guru. Aceh Barat: Kaukaba.

Juwairiyah. (2014). Profesionalisme guru dalam menjalankan KKG dan MGMP. Medan: WI Balai Diklat Keagamaan Medan.

Killion, J. (2005). Evaluating the impact of professional development in eight steps. The Evaluation Change, 11(4).

Lessing, A., \& Witt, M. de. (2007). The value of continuous professional development: teachers' perceptions. South African Journal of Education, 27(1), 53-67.

Loewenberg Ball, D., \& Forzani, F. M. (2009). The work of teaching and the challenge for teacher education. Journal of Teacher Education, 60(5), 497511.

https://doi.org/10.1177/00224871093 48479

Muniroh, J., \& Muhyadi, M. (2017). Manajemen pendidik dan tenaga kependidikan di Madrasah Aliyah Negeri Kota Yogyakarta. Jurnal Akuntabilitas Manajemen Pendidikan,
5(2), 161.

https:// doi.org/10.21831/amp.v5i2.8 050

Petrie, K., \& McGee, C. (2012). Teacher professional development: who is the learner? Australian Journal of Teacher Education, 37(2).

https:/ / doi.org/10.14221/ajte.2012v3 $7 \mathrm{n} 2.7$

Purnanda, A. (2013). Pelaksanaan fungsi kelompok kerja guru (KKG) di sekolah dasar negeri (SDN) Kecamatan Sungai Tarab Kabupaten Tanah Datar. Jurnal Bahana Manajemen Pendidikan, 1(1).

https:// doi.org/http:/ / ejournal.unp. ac.id/index.php/bahana/article/view /2726

Purwoko, S. (2018). Pengaruh kepemimpinan kepala sekolah, komitmen guru, disiplin kerja guru, dan budaya sekolah terhadap kinerja guru SMK. Jurnal Akuntabilitas Manajemen Pendidikan, 6(2), 150. https:// doi.org/10.21831/amp.v6i2.8 467

Tanang, H., \& Abu, B. (2014). Teacher professionalism and professional development practices in South Sulawesi, Indonesia. Journal of Curriculum and Teaching, 3(2). https:// doi.org/10.5430/jct.v3n2p25 